\title{
CORROSION RESISTANCE OF CERIUM-CONVERSION COATINGS FORMED FROM CERIUM(III) SALTS ON ALUMINIUM ALLOY 7075-T6
}

\author{
PETER RODIČa and INGRID MILOŠEV ${ }^{a, *}$
}

\begin{abstract}
Cerium conversion coatings were explored as an alternative to chromate conversion coatings for corrosion protection of aluminium alloy 7075-T6. Conversion coatings were formed in a conversion bath of $0.05 \mathrm{M}$ cerium salt and $0.25 \mathrm{M}$ hydrogen peroxide at room temperature. Various cerium salts were used: $\mathrm{Ce}$ (III) acetate, $\mathrm{Ce}$ (III) nitrate and $\mathrm{Ce}$ (III) chloride. The conversion process from $\mathrm{Ce}^{3+}$ to $\mathrm{Ce}^{4+}$ was followed by UV-VIS spectroscopy. The conversion of cerium coatings on alloy surface was monitored by measuring open circuit potential. To investigate the corrosion properties of uncoated and coated samples, the linear polarization and electrochemical potentiodynamic curves were recorded in $0.1 \mathrm{M} \mathrm{NaCl}$. Additionally, salt spray chamber testing was carried out. Samples were characterized by scanning electron microscopy. Results revealed that the cerium conversion and corrosion resistance were dependent on the type of cerium salt and conversion time in the conversion bath. The most compact and uniform cerium conversion coatings were produced from solution of cerium(III) acetate, but better protection was obtained in nitrate and, especially, chloride solutions due to thicker coatings.
\end{abstract}

Keywords: aluminium alloy 7075-T6, corrosion, cerium conversion coatings, cerium salts

\section{INTRODUCTION}

Aluminium alloys are used in many applications because of their excellent physical characteristics, such as small density, and the high strengthto-weight ratio [1]. Some alloys are heterogeneous and contain numerous intermetallic particles (IMPs) added to increase the strength of aluminium. IMPs are mainly more cathodic (more noble) than aluminium matrix covered by native oxide; the electrochemical heterogeneity increases the susceptibility

\footnotetext{
a Jožef Stefan Institute, Department of Physical and Organic Chemistry, Jamova c. 39, SI1000 Ljubljana, Slovenia

*Corresponding author: ingrid.milosev@ijs.si
} 
of the alloys to corrosion in aggressive environments. 7xxx wrought aluminium alloys contain zinc as a major addition, along with magnesium and copper in combinations that develop various levels of strength. The alloys, which contain copper, have the highest strengths and have been used for more than 50 years as construction materials, primarily in aircraft applications.

Aluminium oxide is stable in aqueous solution in the $\mathrm{pH}$ range of $4.0-9.0$ [2]. At $\mathrm{pH}>9$, aluminium or aluminium - rich oxide will form $\mathrm{AlO}_{2}^{-}$ (aluminate ions), while at $\mathrm{pH}<4$ it will dissolve to form $\mathrm{Al}^{3+}$ ions. The coppercontaining alloys, such as AA7075-T6, have lower resistance to general and localized corrosion than those of the series that do not contain copper [2]. Pitting is the most common type of corrosion attack on aluminium alloy. Pits form at localized discontinuities in the oxide film on aluminium exposed to the aggressive environment. The chloride ions are known to facilitate the breakdown of the aluminium oxide film. The resistance of aluminium to pitting depends significantly on its purity. The reason is the presence of IMPs, especially those with higher copper contents which act as abundant cathodic sites and increase the overall rate of corrosion.

For the protection of aluminium alloys under service conditions, various coatings systems are employed. Chemical conversion coatings are successfully employed for both improving the pitting corrosion resistance and enhancing paint chemical adhesion [3,4]. For many decades, chromate conversion coatings (CCCs) have been used for that purpose. CCCs are particularly effective since chromium species are present in two oxidation states, $\mathrm{Cr}$ (III) and $\mathrm{Cr}(\mathrm{VI})$. The chromium $\mathrm{Cr}(\mathrm{III})$ species provide a barrier protective effect, and the $\mathrm{Cr}(\mathrm{VI})$ species are responsible for "self-repair" effect. The latter is based on the reduction of $\mathrm{Cr}(\mathrm{VI})$ species at the coating defect to form the passivating $\mathrm{Cr}(\mathrm{III})$ oxide $\left(\mathrm{Cr}_{2} \mathrm{O}_{3}\right)$. Unfortunately, the exposure to hexavalent chromium is carcinogenic, and it is now prohibited due to its toxicity, mandating more viable alternatives [5].

Hitherto, alternative chromate-free, systems are unable to match the standards provided by the chromate-containing system, but the results are improving in the last years $[6,7]$. The corrosion resistance of cerium-based conversion coatings (CeCCs) as an environmentally benign alternative to CCCs is being investigated in the last decades. It is well accepted that the inhibition effect of cerium salts on corrosion of aluminium and aluminium alloy is achieved by the protection of cathodic sites for oxygen reduction reaction by cerium oxide/hydroxide precipitates transformed from cerium salts [8, 9]. Hydrogen peroxide $\left(\mathrm{H}_{2} \mathrm{O}_{2}\right)$ is a strong oxidant and its presence in the cerium salt solution can promote oxidation and dissolution of the substrate, which in turn, accelerates the precipitation of the conversion layer [10, 11]. Hydrogen peroxide can also cause the oxidation of $\mathrm{Ce}$ (III) to $\mathrm{Ce}(\mathrm{IV})$, thus affecting the ratio between these species and, consequently, the structure and properties of CeCCs. 
Inhibition mechanism of CeCCs formed from $\mathrm{CeCl}_{3}$ and $\mathrm{Ce}\left(\mathrm{NO}_{3}\right)_{3}$ solutions onto aluminium alloy substrates was studied [12-15]. The local increase in $\mathrm{pH}$ up to 8.5-9 due to cathodic reaction of oxygen reduction establishes the conditions under which the precipitation of $\mathrm{Ce}(\mathrm{OH})_{3}$ takes place $[8,9]$. This insoluble precipitate blocks the cathodic sites and thus diminishes overall corrosion rate. During this process, oxidation of $\mathrm{Ce}$ (III) to $\mathrm{Ce}(\mathrm{IV})$ species occurs as well leading to the mixture of both oxidation states in the final product. In the presence of $\mathrm{H}_{2} \mathrm{O}_{2}$, the oxidation is facilitated.

The purpose of this paper is to investigate the inhibition of corrosion by formation CeCCs. The formation of conversion coating is similar as reported [12]. In our previous studies, we have investigated in detail two methodologies of preparation of rare-earth conversion coatings on aluminium alloys: (i) immersion of metal sample directly in $\mathrm{NaCl}$ solution with rare-earth salts added [16-20], and (ii) preparation of conversion coating separately in a conversion bath containing rare earth salt $[21,22]$. The addition of hydrogen peroxide was studied as well [22]. Our investigations were focused on rare earth salts differing in cation (cerium and lanthanum) $[18,21,22]$ and anion (chloride, nitride, acetate, sulphate) [17]. In the present study, we aimed to investigate the conversion coatings prepared from three types of cerium salts in the presence of $\mathrm{H}_{2} \mathrm{O}_{2}$ and deposited on aluminium alloy 7075-T6. The conversion process was followed using UV-VIS spectroscopy. The electrochemical and corrosion properties of coated and uncoated samples were investigated in $\mathrm{NaCl}$ solution. The optimal CeCCs coatings were additionally tested in the salt spray chamber, and the surface was characterized by scanning electron microscopy coupled with energy dispersive X-ray spectroscopy (SEM/EDS).

\section{RESULTS AND DISCUSSION}

\section{UV-VIS spectroscopy of cerium salts solution}

The conversion of various solutions containing cerium(III) salts after the addition of $\mathrm{H}_{2} \mathrm{O}_{2}$ to conversion bath to stimulate the oxidation of cerium(III) ions to cerium(IV) ions was followed by UV-VIS spectroscopy. Cerium(III) salts are in the form of a white powder or colourless crystals. Their water solutions are colourless; consequently, these solutions do not absorb visible light, but only UV light (UV-A and UV-B) under $350 \mathrm{~nm}$. In contrast, cerium(IV) salts are coloured and their water solutions absorb visible light under $600 \mathrm{~nm}$. The water solutions of cerium(IV) are yellow to orange or even brown. Solution transparency and its colour depends on the type of cerium species formed and on the presence of other anions. 
The kinetics of the conversion was followed for conversion bath containing $0.05 \mathrm{M} \mathrm{Ce}(\mathrm{OAc})_{3}, \mathrm{Ce}\left(\mathrm{NO}_{3}\right)_{3}$ and $\mathrm{CeCl}_{3}$ and $0.25 \mathrm{M} \mathrm{H}_{2} \mathrm{O}_{2}$ (Figure 1). Before the addition of $\mathrm{H}_{2} \mathrm{O}_{2}$, all solutions absorbed only under $330 \mathrm{~nm}$. After the addition of $\mathrm{H}_{2} \mathrm{O}_{2}$, the oxidation process occurred within several minutes (3 $\mathrm{min}$ ), as noticed by increasing intensity of plateau at wavelengths above $350 \mathrm{~nm}$. The oxidation of $\mathrm{Ce}(\mathrm{III})$ to $\mathrm{Ce}$ (IV) ions was reflected in a change of solution colour from transparent to orange (red). Moreover, the important difference in the kinetics of conversion was noticed. The fastest was in $\mathrm{Ce}(\mathrm{OAc})_{3}$ solution, which is observed as a sudden (after $3 \mathrm{~min}$ ) change of colour from transparent to non-transparent red coloured (insert in Figure 1a). On the other hand, the conversion is much slower in $\mathrm{Ce}\left(\mathrm{NO}_{3}\right)_{3}$ and $\mathrm{CeCl}_{3}$ solutions (inserts Figures 1b, c). After $3 \mathrm{~min}$, the solution became slightly yellow coloured. After 20 minutes, the difference in the specta during the conversion was much smaller, but it still slowly continued. After 4 hours, the conversion of $\mathrm{CeCl}_{3}$ was more pronounced than $\mathrm{Ce}\left(\mathrm{NO}_{3}\right)_{3}$, but both still remained lower compared to the conversion of $\mathrm{Ce}(\mathrm{OAc})_{3}$ obtained only after 3 minutes. This result indicated that the conversion of cerium(III) salts in the presence of $\mathrm{H}_{2} \mathrm{O}_{2}$ is strongly related to the associated anions in cerium salt.
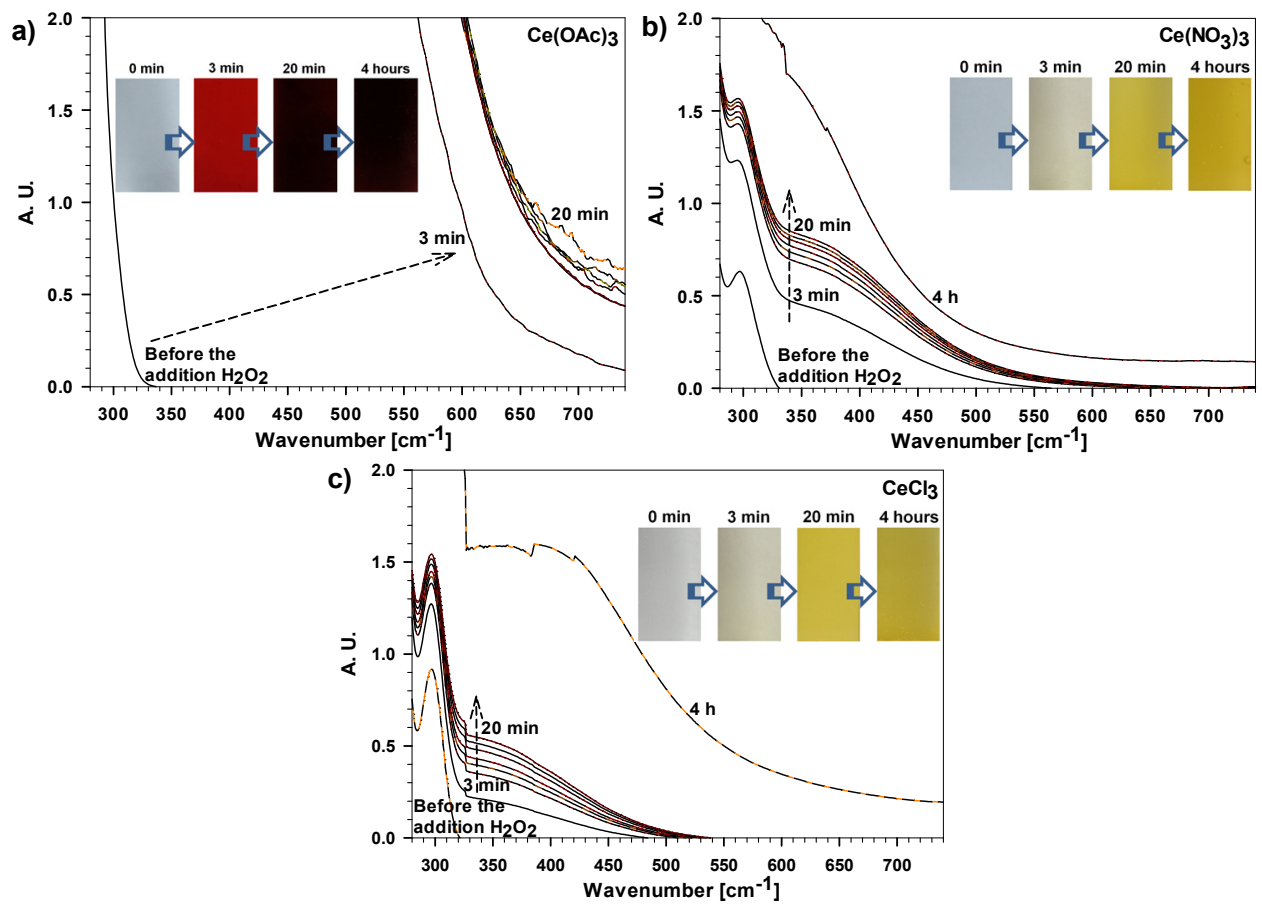

Figure 1. UV-VIS spectra of conversion bath containing $0.05 \mathrm{M} \mathrm{Ce}$ (III) salt and $0.25 \mathrm{M} \mathrm{H}_{2} \mathrm{O}_{2}$ : (a) $\mathrm{Ce}(\mathrm{OAc})_{3}$, (b) $\mathrm{Ce}\left(\mathrm{NO}_{3}\right)_{3}$ and (c) $\mathrm{CeCl}_{3}$. The inset figures show the changes of the solutions colours in the cuvettes during conversion. 


\section{Electrochemical measurements}

CeCC formation

CeCCs were deposited on AA7075-T6. Before deposition, the substrates were ground with emery papers. The samples were then immersed in $0.05 \mathrm{M}$ cerium salt, Figure 2. Immediately after, hydrogen peroxide $\left(\mathrm{H}_{2} \mathrm{O}_{2}\right)$ as an oxidation reagent was added to the solution to obtain $0.25 \mathrm{M}$ concentration. Samples were immersed in conversion bath at room temperature for different periods of time (from 3 min to 4 h) (Figure 2).

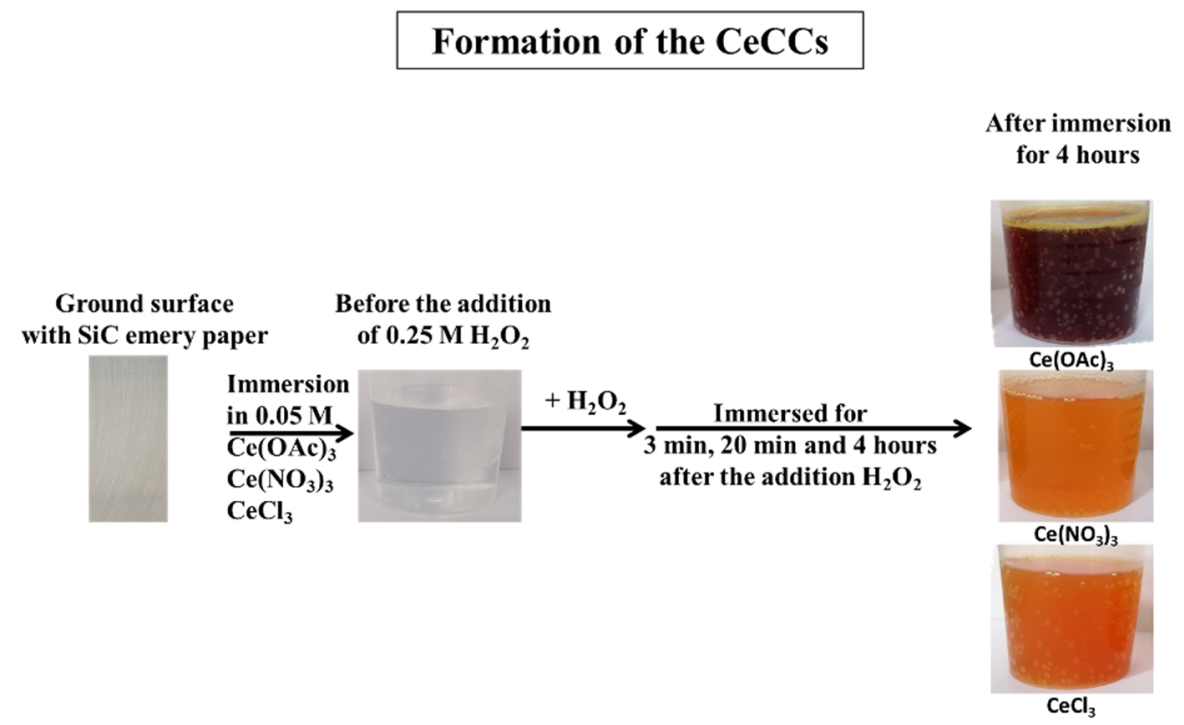

Figure 2. Schematic presentation of CeCCs formation during immersion of AA7075-T6 in conversion bath containing $0.05 \mathrm{M}$ of $\mathrm{Ce}(\mathrm{III})$ salt $\left(\mathrm{Ce}(\mathrm{OAc})_{3}\right.$, $\mathrm{Ce}\left(\mathrm{NO}_{3}\right)_{3}$ or $\left.\mathrm{CeCl}_{3}\right)$ and $0.25 \mathrm{M} \mathrm{H}_{2} \mathrm{O}_{2}$.

The formation of cerium conversion coatings on AA7075-T6 surface as a function of immersion time in a solution containing $\mathrm{Ce}(\mathrm{OAc})_{3}, \mathrm{Ce}\left(\mathrm{NO}_{3}\right)_{3}$ and $\mathrm{CeCl}_{3}$ was monitored using open circuit potential, $\left(E_{\mathrm{oc} \text { form}}\right)$, Figure 3 . $E_{\mathrm{oc} \text { form }}$ in cerium solution depends on cerium salt. The most negative value was obtained in $\mathrm{Ce}(\mathrm{OAc})_{3}$ solution. This confirmed the importance of the anions present in the solution, where $\mathrm{OAc}^{-}$and $\mathrm{Cl}^{-}$ions are more aggressive for AA7075-T6 compared to $\mathrm{NO}_{3}{ }^{-}$. The $\mathrm{pH}$ values of cerium salts solutions $\left(\mathrm{pH}_{\text {sol }}\right)$ are neutral $\left(\mathrm{Ce}(\mathrm{OAc})_{3} ; \mathrm{pH}_{\mathrm{sol}}=7.2\right)$ or slightly acidic $\left(\mathrm{Ce}\left(\mathrm{NO}_{3}\right)_{3} \quad \mathrm{pH}_{\text {sol }}=5.2\right.$ and $\mathrm{CeCl}_{3}$ $\mathrm{pH}_{\mathrm{so}}=5.2$ ), Figure $3 a$. However, after addition $\mathrm{H}_{2} \mathrm{O}_{2}$ into solution, $E_{\text {oc form }}$ rapidly increased for a few hundreds $\mathrm{mV}$ to less negative vales and after 3 minutes of 
immersion, reached the first maximum (Figure 3a). This indicated the start of the formation of cerium film on the aluminium surface. After the addition $\mathrm{H}_{2} \mathrm{O}_{2}$, $\mathrm{pH}$ decreased to much lower $\mathrm{pH}$ values (solution became acidic), where the passive aluminium film is not stable. At the beginning of conversion, the $\mathrm{pH}$ was between 2.8 and 3.3 (insert Figure $3 \mathrm{~b}$ ). Such conditions accelerate the formation of cerium film on the surface. During the course of the conversion, the $\mathrm{pH}$ slightly decreased for $\mathrm{CeCl}_{3} \mathrm{CeCC}$, increased for $\mathrm{Ce}(\mathrm{OAc})_{3} \mathrm{CeCC}$, and remained unchanged for $\mathrm{Ce}\left(\mathrm{NO}_{3}\right)_{3} \mathrm{CeCC}$. After 20 minutes of immersion, the $E_{\text {oc form }}$ for $\mathrm{CeCl}_{3}$, become more constant confirming the formation of more stable (thicker) cerium conversion film. However, the formation continued at longer immersion time, but after 4 hours, the $E_{\text {oc form }}$ became constant in all immersed solutions (Figure $3 \mathrm{~b}$ ). The colours of the final solutions are shown in Figure 2 and are comparable with colours monitored with UV-VIS (Figure 1). It can be concluded that the conversion of cerium in water solution is mainly related to the presence of $\mathrm{H}_{2} \mathrm{O}_{2}$ in the conversion bath.
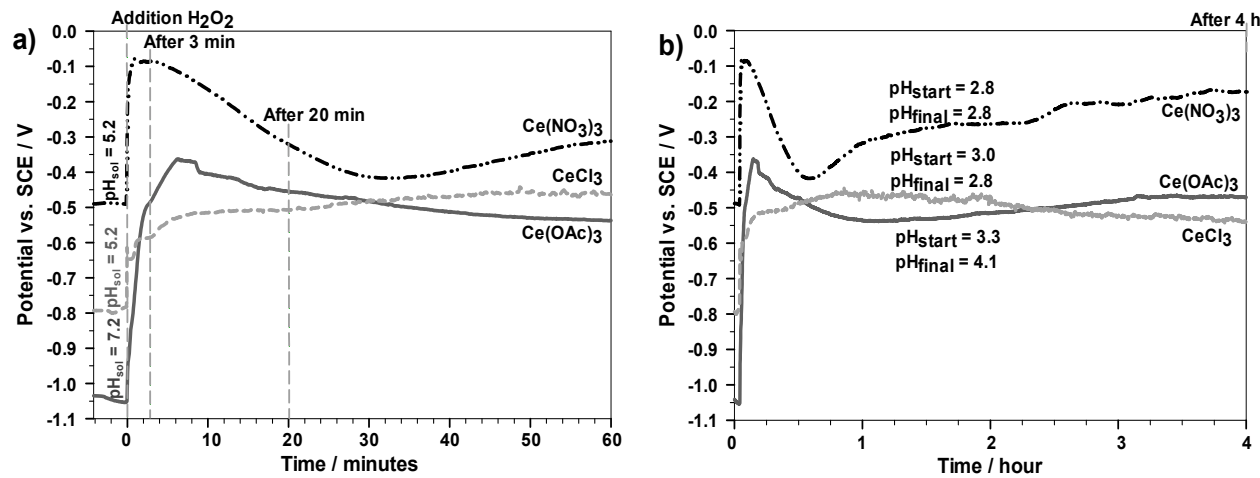

Figure 3. Open circuit potentials of AA7075-T6 during CeCCs formation for various conversion times (a) first hour and (b) up to 4 hours in conversion bath of $0.05 \mathrm{M}$ of different cerium salts with $0.25 \mathrm{M} \mathrm{H}_{2} \mathrm{O}_{2}$ added. The inserted values represent the $\mathrm{pH}$ of the cerium solution $\left(\mathrm{pH}_{\mathrm{sol}}\right)$ and $\mathrm{pH}$ values of the conversion solution after addition $\mathrm{H}_{2} \mathrm{O}_{2}\left(\mathrm{pH}_{\text {start }}\right)$ and after 4 hours of immersion in conversion bath $\left(\mathrm{pH}_{\text {final }}\right)$.

After immersion of the aluminium sample in conversion bath, the colour of the aluminium surface was changed from metallic grey to orange-green due to the formation of cerium conversion coating on its surface (Figure 2). The precipitation of cerium (III) and cerium(IV) oxide/hydroxide islands at the metal surface has been presented in the literature $[10,18,21,22]$ and in our previous studies $[16,17,20,22]$. Herein the mechanism of cerium conversion on aluminium alloy is presented schematically in Figure 4. 


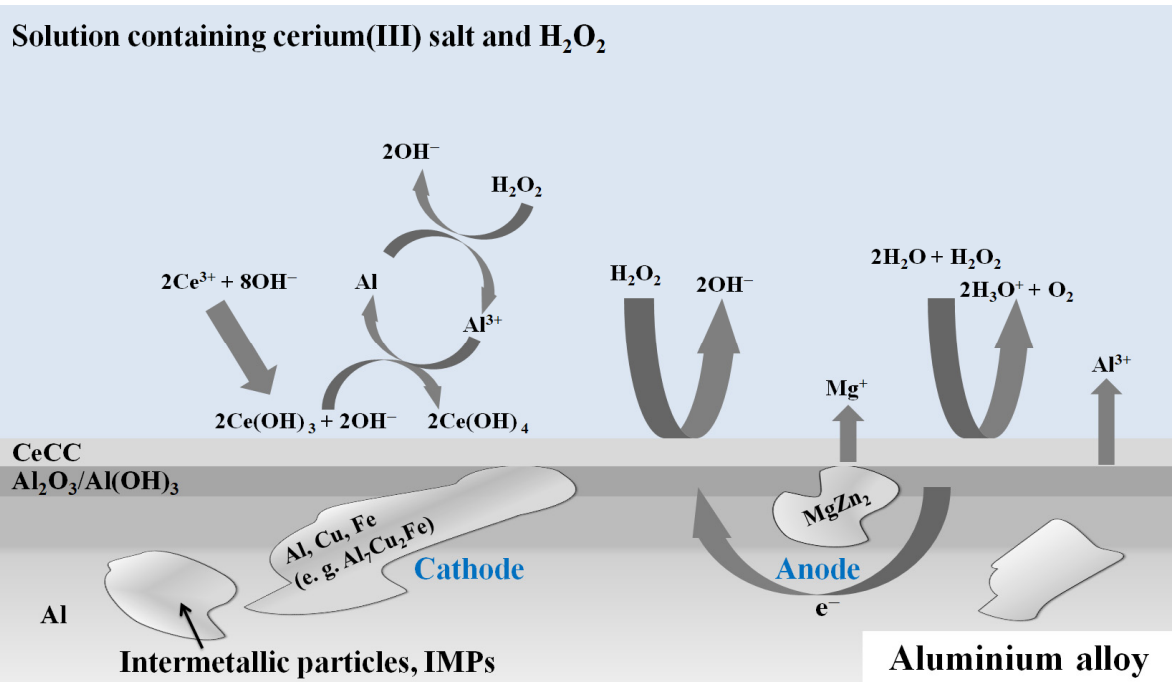

Figure 4. Schematic presentation of formation CeCCs on aluminium alloy.

Briefly, the cerium conversion coating is formed due to the oxidation of $\mathrm{Ce}^{3+}$ into $\mathrm{Ce}^{4+}$ in the presence of $\mathrm{OH}^{-}$ions formed locally on the aluminium alloy surface. The process is accelerated in the presence of $\mathrm{H}_{2} \mathrm{O}_{2}$, where the $\mathrm{OH}^{-}$ions are also formed due to its decomposition. The critical impact in the formation of the film presents the intermetallic particles, IMPs. Therefore, the film formation starts at the cathodic sites of these IMPs and later (after more extended conversion) throughout the whole aluminium surface.

\section{Corrosion testing}

Once the AA7075-T6 samples were coated, they were subject to the electrochemical measurements. First, samples were allowed to rest for one hour of immersion in the corrosive medium of $0.1 \mathrm{M} \mathrm{NaCl}$. The electrochemical measurements were performed on conversion coatings formed for different periods of immersion in cerium conversion solution ( $3 \mathrm{~min}, 20 \mathrm{~min}$ and 4 hours) (Figure 2). The electrochemical corrosion parameters determined from potentiodynamic polarization measurements for bare and coated AA7075-T6 samples are presented in Table 1 and polarization curves are presented in Figure 5. Polarization curve of bare sample consists of cathodic part related to 
oxygen reduction and anodic part related to the dissolution of $\mathrm{Al}[16,19,23]$. Bare AA7075-T6 shows poor corrosion resistance, as reflected in small $R_{\mathrm{p}}$, large $j_{\text {corr }}$ and immediate rise in current density following the $E_{\text {corr. }}$ In the absence of the coating, the chloride solution is in contact with the metal surface (mainly cathodic intermetallic particles) and the porous aluminium oxide surface film.

When coated, the improvement of corrosion characteristics is dependent on the type of cerium salt and time of immersion in the conversion bath. The porous layer, especially the cathodic sites, is additionally protected by the precipitated cerium-based layer.

Table 1. Electrochemical parameters in $0.1 \mathrm{M} \mathrm{NaCl}$ for non-coated AA7075-T6 and coated with different CeCCs formed for various conversion times in conversion bath of $0.05 \mathrm{M}$ of cerium salt with $0.25 \mathrm{M} \mathrm{H}_{2} \mathrm{O}_{2}$ added.

\begin{tabular}{|c|c|c|c|c|c|c|}
\hline & $R_{\mathrm{p}}\left[\mathrm{k} \Omega \mathrm{cm}^{2}\right]$ & $j_{\text {corr }}\left[\mathrm{nA} / \mathrm{cm}^{2}\right]$ & $E_{\text {corr }}[\mathrm{V}]$ & $E_{\text {pit }}[\mathrm{V}]$ & $\Delta E[\mathrm{mV}]$ & \\
\hline \begin{tabular}{|l|} 
Ground \\
AA7075-T6 \\
\end{tabular} & 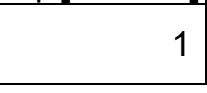 & 1860 & -0.70 & -0.69 & 10 & \\
\hline $\begin{array}{l}\text { Conversion } \\
\text { time } 3 \text { min }\end{array}$ & $R_{\mathrm{p}}\left[\mathrm{k} \Omega \mathrm{cm}^{2}\right]$ & $j_{\text {corr }}\left[\mathrm{nA} \mathrm{cm}\right.$ cm $\left.^{2}\right]$ & $E_{\text {corr }}[\mathrm{V}]$ & $E_{\text {pit }}[\mathrm{V}]$ & $\Delta E[\mathrm{mV}]$ & IE [ \\
\hline $\mathrm{Ce}(\mathrm{OAc})_{3}$ & 8 & 199 & -0.70 & -0.69 & 10 & 87.5 \\
\hline $\mathrm{Ce}\left(\mathrm{NO}_{3}\right)_{3}$ & 3 & 1636 & -0.69 & -0.68 & 10 & 66 \\
\hline $\mathrm{CeCl}_{3}$ & 27 & 64 & -0.69 & -0.68 & 10 & 96.3 \\
\hline
\end{tabular}

\begin{tabular}{|l|r|r|r|r|r|r|}
\hline $\begin{array}{l}\text { Conversion } \\
\text { time 20 min }\end{array}$ & $\boldsymbol{R}_{\mathbf{p}}\left[\mathbf{k} \boldsymbol{\Omega} \mathbf{~ c m}^{2}\right]$ & $j_{\text {corr }}\left[\mathbf{n A ~ \mathbf { ~ c m } ^ { 2 } ]}\right.$ & $E_{\text {corr }}[\mathbf{V}]$ & $\boldsymbol{E}_{\text {pit }}[\mathbf{V}]$ & $\Delta E[\mathbf{m V}]$ & IE [\%] \\
\hline $\mathrm{Ce}(\mathrm{OAc})_{3}$ & 32 & 324 & -0.77 & -0.68 & 90 & 95.3 \\
\hline $\mathrm{Ce}\left(\mathrm{NO}_{3}\right)_{3}$ & 3 & 1827 & -0.67 & -0.66 & 10 & 66.7 \\
\hline $\mathrm{CeCl}{ }_{3}$ & 34 & 394 & -0.78 & -0.69 & 90 & 97.0 \\
\hline
\end{tabular}

\begin{tabular}{|l|r|r|r|r|r|r|}
\hline $\begin{array}{l}\text { Conversion } \\
\text { time 4 h }\end{array}$ & $\boldsymbol{R}_{\mathbf{p}}\left[\mathbf{k} \boldsymbol{\Omega} \mathbf{~ c m}^{2}\right]$ & $j_{\text {corr }}\left[\mathrm{nA} \mathrm{cm}^{2}\right]$ & $E_{\text {corr }}[\mathbf{V}]$ & $\boldsymbol{E}_{\text {pit }}[\mathbf{V}]$ & $\Delta E[\mathbf{m V}]$ & IE [\%] \\
\hline $\mathrm{Ce}(\mathrm{OAc})_{3}$ & 13 & 551 & -0.98 & -0.69 & 290 & 76.9 \\
\hline $\mathrm{Ce}\left(\mathrm{NO}_{3}\right)_{3}$ & 248 & 122 & -0.67 & 0.23 & 900 & 99.4 \\
\hline $\mathrm{CeCl}{ }_{3}$ & 555 & 70 & -0.52 & -0.01 & 510 & 99.7 \\
\hline
\end{tabular}

For $\mathrm{CeCl}_{3}$ and $\mathrm{Ce}\left(\mathrm{NO}_{3}\right)_{3} \mathrm{CeCCs}$, the conversion time has a decisive role on the improvement of corrosion parameters (Figure 5). For shorter conversion times, up to $20 \mathrm{~min}$, the polarization curves did not differ considerably compared to that of bare alloy; $j_{\text {corr }}$ was smaller and the $E_{\text {corr }}$ shifted somewhat more negative, but no passive range was established. The inhibition efficiency (IE) was below $97 \%$. However, after $4 \mathrm{~h}$ conversion, both $\mathrm{CeCl}_{3}$ and $\mathrm{Ce}\left(\mathrm{NO}_{3}\right)_{3} \mathrm{CeCC}$ s exhibited different curves with strongly reduced 
$j_{\text {corr }}$ and $E_{\text {corr }}$ shifted to more positive direction giving $\Delta E$ of $0.5 \mathrm{~V}$ and $0.9 \mathrm{~V}$, respectively. The extension of $\Delta E$ reflects significantly improved resistance of the coated surface to initiation of pitting corrosion. These coatings act like mixed inhibitors with a stronger effect on the anodic part.

The $\mathrm{Ce}(\mathrm{OAc})_{3} \mathrm{CeCC}$ showed improved corrosion parameters only after $4 \mathrm{~h}$ conversion time; the $E_{\text {corr }}$ was shifted more negative and passive plateau was established but the $E_{\text {pit }}$ did not exceed that of uncoated alloy. Despite faster conversion in the presence of $\mathrm{H}_{2} \mathrm{O}_{2}$, the cerium coating formation is slow. The cerium ions rather precipitate into solution instead of forming the film on the aluminium surface. In contrast to chloride and nitrate $\mathrm{CeCCs}$, acetate $\mathrm{CeCC}$ shows less corrosion protection ability and acts as a cathodic inhibitor, i.e. opposite to former two, which show strong anodic inhibition. Acetate coating
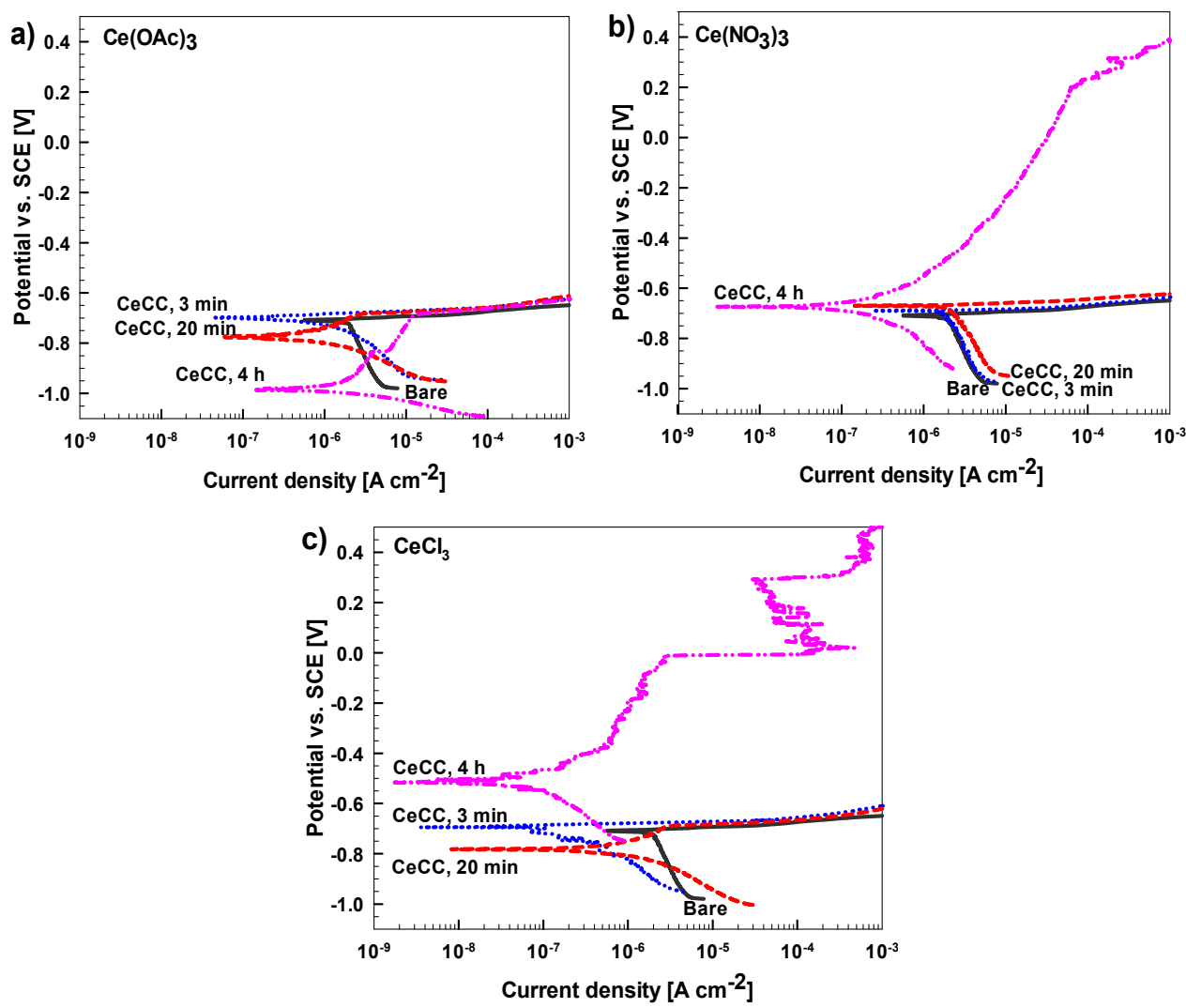

Figure 5. Electrochemical polarization curves recorded in $0.1 \mathrm{M} \mathrm{NaCl}$ for bare AA7075-T6 and coated with CeCCs formed for various conversion times in conversion bath of $0.05 \mathrm{M}$ of different cerium salts with $0.25 \mathrm{M} \mathrm{H}_{2} \mathrm{O}_{2}$ added. Stabilization at the $E_{\mathrm{oc}}$ was $1 \mathrm{~h}$. 
did not benefit from prolonged conversion time. Comparing $\mathrm{CeCl}_{3}$ and $\mathrm{Ce}\left(\mathrm{NO}_{3}\right)_{3} \mathrm{CeCCs}$, the former show better characteristics: nitrate $\mathrm{CeCC}$ exhibits broader $\Delta E$ range but the current densities are greater and progressively increase. In terms of inhibitions efficiency $\mathrm{IE}, \mathrm{CeCl}_{3}$ and $\mathrm{Ce}\left(\mathrm{NO}_{3}\right)_{3} \mathrm{CeCC}$ reach the highest value, more than $99 \%$.

\section{Test in salt spray chamber}

Good corrosion properties of selected CeCCs were confirmed with salt spray test. The images of uncoated and coated AA7075-T6 samples after different times of exposure in salt spray chamber were compared in Figure 6. The CeCCs were formed in $0.05 \mathrm{M} \mathrm{Ce}(\mathrm{OAc})_{3}, \mathrm{Ce}\left(\mathrm{NO}_{3}\right)_{3}$ and $\mathrm{CeCl}_{3}$ solutions with addition $0.25 \mathrm{M} \mathrm{H}_{2} \mathrm{O}_{2}$ and conversion time of $4 \mathrm{~h}$. This procedure was selected based on the most efficient results obtained from potentiodynamic measurements (Figure 5).

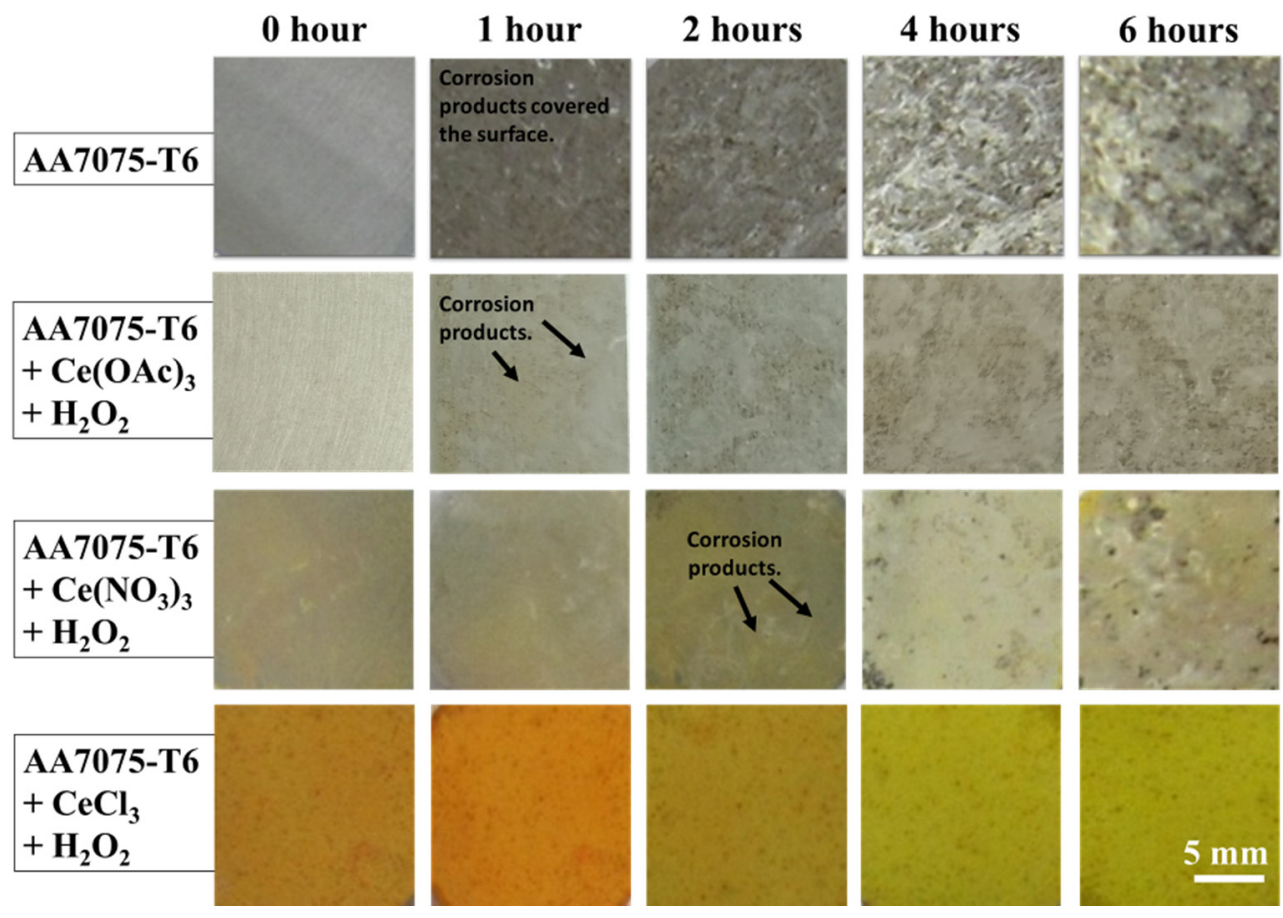


Figure 6. Surface appearance after salt spray test at different periods of time for bare AA7075-T6 and coated with CeCCs formed for conversion time of $4 \mathrm{~h}$ in $\mathrm{Ce}(\mathrm{OAc})_{3}, \mathrm{Ce}\left(\mathrm{NO}_{3}\right)_{3}$ and $\mathrm{CeCl}_{3}$ solutions after the addition of $0.25 \mathrm{M} \mathrm{H}_{2} \mathrm{O}_{2}$.

AA7075-T6 is not stable in chloride media and corrosion products covering the whole surface can be seen after only 1 hour. The amount of products increase during the extended exposure time (Figure 6). The protection with CeCCs improved the corrosion resistance. $\mathrm{Ce}(\mathrm{OAc})_{3}, \mathrm{Ce}\left(\mathrm{NO}_{3}\right)_{3}$ and, especially, $\mathrm{CeCl}_{3} \mathrm{CeCC}$ were oxidized to cerium $\mathrm{Ce}(\mathrm{IV})$ which is evident from the yellow colour characteristic of the presence of cerium in oxidation state (IV). However, the difference in the coating durability was noticed. Slight improvement in corrosion resistance of the formed film was obtained for $\mathrm{Ce}(\mathrm{OAc})_{3} \mathrm{CeCC}$. The first corrosion products are observed after 1 hour, but the amount of them is lower compared to bare AA7075-T6. Better corrosion protection was obtained for $\mathrm{Ce}\left(\mathrm{NO}_{3}\right)_{3} \mathrm{CeCC}$ because first corrosion products were observed after 2 hours. However, both $\mathrm{Ce}(\mathrm{OAc})_{3}$ and $\mathrm{Ce}\left(\mathrm{NO}_{3}\right)_{3} \mathrm{CeCCs}$ were not resistant after longer exposure ( 4,6 hours) and the corrosion products were formed on the surface. The most durable protective was obtained for $\mathrm{CeCl}_{3} \mathrm{CeCC}$, where corrosion products were not observed even after 6 hours. From the effectiveness point of view, the use of conversion coatings based on $\mathrm{CeCl}_{3}$ and $\mathrm{Ce}\left(\mathrm{NO}_{3}\right)_{3}$ is justified.

\section{SEM/EDS characterization}

SEM/EDS was used to characterize surface morphology of AA7075T6 prior to and after coated with CeCCs (Figure 7). Chemical composition determined at different spots at the sample surface is presented in Table 2. The matrix of bare AA7075-T6 consists of Al, and some other metal elements mainly $\mathrm{Zn}, \mathrm{Mg}$ and $\mathrm{Cu}$, which are dispersed in the structure (Figure 7a, spot 1). Bare sample also contains $\mathrm{Cu}$ - and Fe-based IMPs (spots 2,3) which present cathodic spots relative to aluminium oxide matrix (spot 1).

The changes in the surface morphology can be noticed after immersion AA7075-T6 during 4 hours formation CeCCs. Coatings largely differ in morphology: acetate coating seems to be much thinner but much more homogeneous compared to nitrate and chloride CeCCs (Figure 7b). Cerium was detected at the coating surface (spot 5). Some defects were noted where the coating was delaminated and revealed bare alloy surface (spot 4). Nitrate coating seemed thicker than acetate coating but cracked (Figure 7c). However, cerium was detected at the surface of the coating and within the cracks (points 6 and 7). As for acetate, for nitrate coatings the formation of 
Ce-coating was related to Cu-based IMPs. Some defects were observed at the surface. Chloride coating appeared even more cracked and thicker

(Figure 7d). Chloride coating contained a large amount of Ce (point 8) and no Al was detected, indicating that the alloy surface was fully covered with few micrometres thick CeCC.

Cracks may form during exposure of the coatings to vacuum within the microscope chamber but may also be related to the inherent properties of the coatings due to its large thickness and consequent internal stress. The cracks initiation is dependent on a number of factors; conversion time, type of cerium ions and hydrogen peroxide concentration and $\mathrm{pH}$ of the conversion solution affect the composition and morphology of the coatings formed, which is also reflected on corrosion properties. Another important parameter is the evaporation of the water during the drying process. Thus, the coating with large thickness will be more susceptible to cracking.

Table 2. EDS analysis results performed on the marked areas in Figure 7 on (a) ground AA7075-T6 and coated with CeCCs formed from $0.05 \mathrm{M}$ (b) $\mathrm{Ce}(\mathrm{OAc})_{3}$,

(c) $\mathrm{Ce}\left(\mathrm{NO}_{3}\right)_{3}$ and (d) $\mathrm{CeCl}_{3}$ solution in the presence of $0.25 \mathrm{M} \mathrm{H}_{2} \mathrm{O}_{2}$.

\begin{tabular}{|l|l|l|l|l|l|l|l|}
\hline \multicolumn{7}{|c|}{ Elements, given in weight percentage (wt. \%) } \\
\hline Spots & Zn & Mg & Fe & Cu & O & Ce & Al \\
\hline $\mathbf{1}$ & 7.4 & 2.2 & - & 2.5 & 0.9 & - & 87.0 \\
\hline $\mathbf{2}$ & 1.4 & - & 11.1 & 32.0 & 4.2 & - & 51.3 \\
\hline $\mathbf{3}$ & - & - & 10.4 & 30.7 & 4.7 & - & 54.2 \\
\hline \multicolumn{7}{|l|}{} \\
\hline $\mathbf{4}$ & 5.6 & 1.6 & - & 1.4 & 25.2 & - & 66.2 \\
\hline $\mathbf{5}$ & 5.4 & 1.9 & - & 1.5 & 25.9 & 1.6 & 63.7 \\
\hline \multicolumn{7}{|l|}{} \\
\hline $\mathbf{6}$ & - & 0.8 & - & 2.7 & 14.5 & 16.7 & 65.3 \\
\hline $\mathbf{7}$ & - & 1.1 & - & 5.8 & 19.2 & 17.5 & 56.4 \\
\hline & - & - & - & 13.9 & 86.1 & - \\
\hline $\mathbf{8}$ & - & - & - &
\end{tabular}


FROM CERIUM(III) SALTS ON ALUMINIUM ALLOY 7075-T6
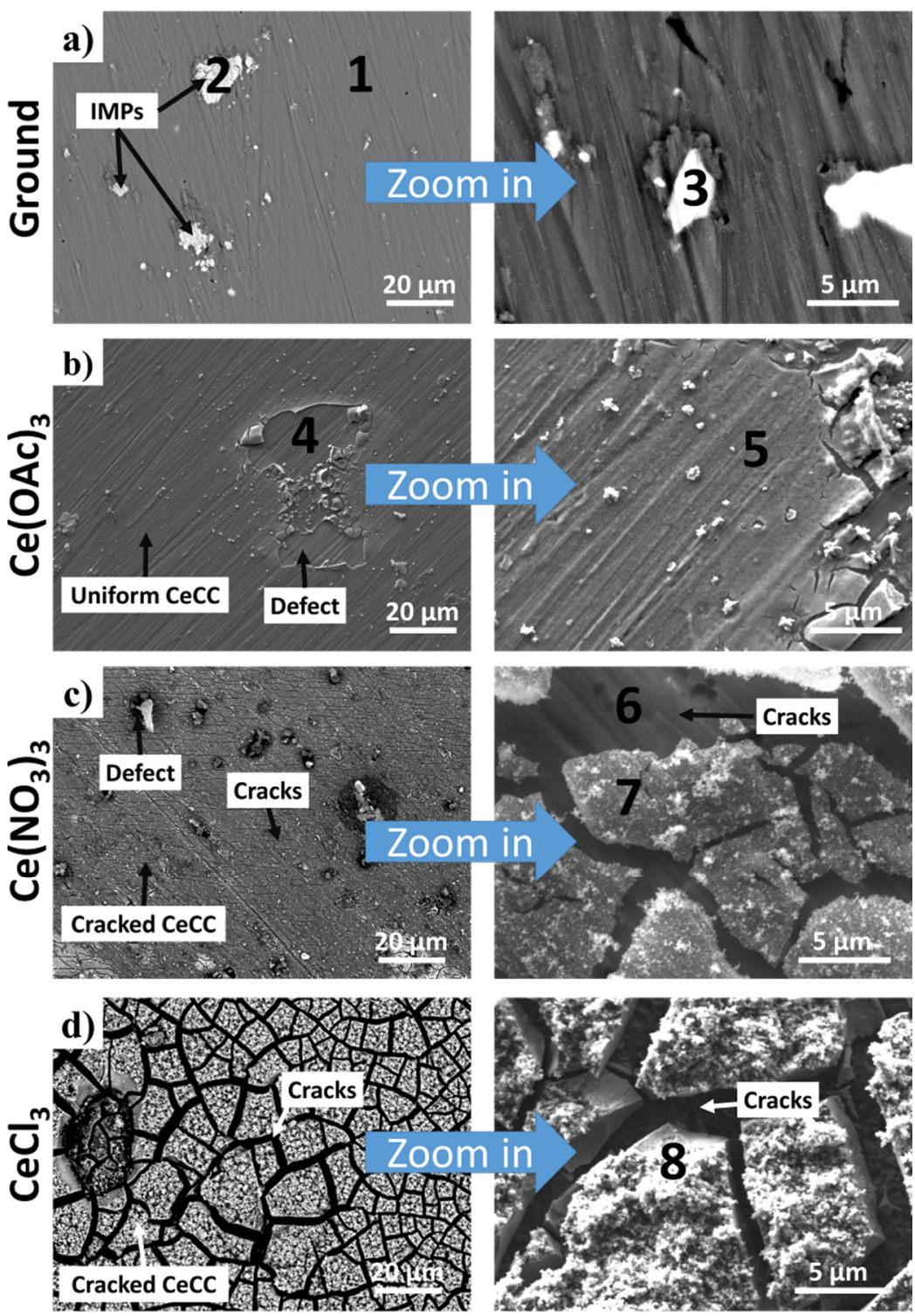

Figure 7. Backscattered SEM images (COMPO) mode of (a) ground AA7075-T6 and coated with CeCCs formed from (b) $0.05 \mathrm{M} \mathrm{Ce}(\mathrm{OAc})_{3}$, (c) $0.05 \mathrm{M} \mathrm{Ce}\left(\mathrm{NO}_{3}\right)_{3}$ and (d) $0.05 \mathrm{M} \mathrm{CeCl}_{3}$ solutions. All coatings were formed with $0.25 \mathrm{M} \mathrm{H}_{2} \mathrm{O}_{2}$ added and conversion time was 4 hours. SEM images were taken at lower $(1000 \times$, left column) and higher magnification (5000×, right column). The arrows note the intermetallic particles (IMPs), CeCC, cracks in the coating and defects. 


\section{CONCLUSIONS}

Cerium conversion coatings (CeCCs) were formed by deposition of cerium oxide/hydroxide from the water-based solution of different $\mathrm{Ce}$ salts on AA7075-T6 substrates. The conversion was carried out in $0.05 \mathrm{M}$ solution of $\mathrm{Ce}$ salts (chloride, nitrate and acetate) for different conversion times in the presence of $\mathrm{H}_{2} \mathrm{O}_{2}$ as oxidant agent.

The corrosion protection the uncoated and coated AA7075-T6 was studied by electrochemical measurements in $0.1 \mathrm{M} \mathrm{NaCl}$ solution and salt spray chamber test in $5 \mathrm{wt} \% \mathrm{NaCl}$. Both $\mathrm{CeCl}_{3}$ or $\mathrm{Ce}\left(\mathrm{NO}_{3}\right)_{3} \mathrm{CeCC}$ showed similar performance in terms of electrochemical and salt spray chamber results. When longer conversion time of $4 \mathrm{~h}$ was used to deposit coatings on AA7075-T6, the nitrate and chloride-based CeCCs act as strong anodic inhibitors, and acetate-based $\mathrm{CeCC}$ acts as cathodic inhibitor in chloride solution. Salt spray test confirmed low protective ability of acetate, better in nitrate and the best in chloride-based CeCCs.

The morphology of the coatings is abundant; in the case of acetate $\mathrm{CeCC}$ the surface was uniformly covered, whereas nitrate- and chloridebased coatings were susceptible to cracking, probably due to larger thickness.

To conclude, selected cerium conversion coatings showed the ability to protect AA7075-T6 under moderate, non-rigorous corrosive conditions. Coatings are relatively easy to prepare, are low-cost and non-toxic.

\section{EXPERIMENTAL SECTION}

\section{Materials and chemicals}

\section{Metal substrates}

Aluminium alloy 7075-T6, in the form of $0.5 \mathrm{~mm}$ thick sheet supplied by Kaiser Aluminum, USA, was used as a substrate. Sheets were cut into disks of 15-mm diameter. Before deposition, the substrates were ground with 2400- and 4200-grit SiC emery papers (Struers, The Netherlands), rinsed with distilled water and cleaned ultrasonically in ethanol for 10 minutes.

\section{Chemicals and procedure for formation of conversion coatings}

A $50 \mathrm{~mL}$ volume of $0.05 \mathrm{M}$ cerium salt was prepared in a $100 \mathrm{~mL}$ beaker serving as a conversion bath. Then the sample was positioned at the bottom of the beaker with the ground surface facing up. Immediately after, hydrogen peroxide $\left(\mathrm{H}_{2} \mathrm{O}_{2}, 30 \%\right.$, AppliChem) as an oxidation reagent was added to the solution to obtain $0.25 \mathrm{M}$ concentration (Figure 2). 
Samples were immersed in conversion bath at room temperature for different periods of time (from 3 min to $4 \mathrm{~h}$ ) and then taken out, rinsed with distilled water for ten minutes and dried with a jet of compressed air.

Cerium conversion coatings were formed from various cerium(III) salts were used: $\mathrm{Ce}(\mathrm{III})$ acetate $\left(\mathrm{Ce}(\mathrm{OAc})_{3}: \mathrm{Ce}\left(\mathrm{CH}_{3} \mathrm{COO}\right)_{3} \times 2 \mathrm{H}_{2} \mathrm{O}, 99.9 \%\right.$, Aldrich), $\mathrm{Ce}$ (III) chloride $\left(\mathrm{CeCl}_{3} \times 7 \mathrm{H}_{2} \mathrm{O}, 99.9 \%\right.$, Aldrich) and $\mathrm{Ce}(\mathrm{III})$ nitrate $\times \mathrm{H}_{2} \mathrm{O}$ $\left(\mathrm{Ce}\left(\mathrm{NO}_{3}\right)_{3}, 99.5 \%\right.$, Fluka). The content of crystal-bound water in cerium(III) acetate was calculated from the thermogravimetric analysis.

\section{Methods}

\section{UV-VIS spectroscopy}

UV-VIS spectra were recorded with a Perkin-Elmer Lambda 25 UV-VIS spectrophotometer. Samples were immersed in a $1 \mathrm{~cm}$ wide disposable plastic makro cuvettes (Ratiolab GmbH, Dreieich, Germany) then placed in the holder in the UV spectrometer. Spectra were measured between a wavelength from $700 \mathrm{~nm}$ to $280 \mathrm{~nm}$ as absorbance spectra. The spectra were recorded every 3 minutes and are presented as absorbance units (A. U.).

\section{Corrosion measurements}

\section{Electrochemical measurements}

Electrochemical measurements were performed in a three-electrode standard corrosion cell (Parstat - Corrosion Cell Kit, model K0047, volume $1 \mathrm{~L}$ ) at $25^{\circ} \mathrm{C}$. Bare, uncoated AA7075-T6 samples coated by conversion coatings were embedded in a Teflon holder (model K0105 Flat Specimen Holder Kit) served as a working electrode. An area of $0.95 \mathrm{~cm}^{2}$ was exposed to the corrosive solution. A saturated calomel electrode ( $\mathrm{SCE}, \mathrm{Hg} / \mathrm{Hg}_{2} \mathrm{Cl}_{2}, 0.242 \mathrm{~V}$ vs. saturated hydrogen electrode) was used as reference electrode together with reference electrode bridge tube and carbon rods as a counter electrode. All potentials in the text refer to the SCE electrode. Electrochemical experiments were carried out with an Autolab PGSTAT 12 (Metrohm Autolab, Utrecht, The Netherlands) potentiostat/galvanostat and controlled by Nova 2.1 software.

During the formation of $\mathrm{CeCC}$ in the conversion bath, the open circuit potential was measured as a function of time prior and after addition of $\mathrm{H}_{2} \mathrm{O}_{2}$ until a steady-state value was achieved, referred to as $E_{\text {oc form. }}$. 
The corrosion performance of uncoated and coated samples was investigated in $0.1 \mathrm{M} \mathrm{NaCl}$ solution ( $\mathrm{NaCl}$, AppliChem > 99.5\%) of $\mathrm{pH}=5.2$. Solution was prepared using Milli-Q Direct water with the resistivity of 18.2 $\mathrm{M} \Omega \mathrm{cm}$ at $25^{\circ} \mathrm{C}$ (Millipore, Billerica, MA).

Prior to measurements, the samples were allowed to stabilize under open circuit conditions for approximately $1 \mathrm{~h}$. During that time, the open circuit potential was measured as a function of time until a steady potential was achieved (referred to as $E_{\mathrm{oc}}$ ). Following stabilization at the $E_{\mathrm{oc}}$, the electrochemical measurements were carried out. The linear polarization measurements were performed in a potential range of $\pm 10 \mathrm{mV}$ vs. $E_{\mathrm{oc}}$, using a $0.1 \mathrm{mV} / \mathrm{s}$ potential scan rate. The values of polarization resistance $\left(R_{\mathrm{p}}\right)$ were deduced from the slope of fitted current density vs. potential lines using Nova software. Potentiodynamic measurements were performed using a $1 \mathrm{mV} / \mathrm{s}$ potential scan rate, starting $-250 \mathrm{mV}$ to $E_{\mathrm{oc}}$. The potential was then increased in the anodic direction. For each sample, measurements were performed at least in triplicate and the representative measurement was chosen to be presented in graphs. Related electrochemical corrosion parameters (corrosion potential $\left(E_{\text {corr }}\right)$, corrosion current density $\left(j_{\text {corr }}\right)$ ) were obtained from polarization curves by Tafel approximation. The difference between the pitting potential $\left(E_{\text {pit }}\right)$ and $E_{\text {corr }}$ was denoted as a passive span and calculated as $\Delta E=\left|E_{\text {pit }}-E_{\text {corr }}\right|$. Some polarization curves with not well defined anodic Tafel region were extrapolated by inspecting only a linear fit of the cathodic Tafel curve, which intersects the $E_{\text {corr. }}$

The corrosion inhibition efficiency (IE) was determined from linear polarization and calculated using the equation:

$$
\mathrm{IE}=\frac{R_{\mathrm{p}}^{*}-R_{\mathrm{p}}}{\mathrm{R}_{\mathrm{p}}^{*}}
$$

where $R_{\mathrm{p}}{ }^{*}$ and $R_{\mathrm{p}}$ are polarization resistance measured on coated and uncoated samples.

\section{Salt spray test}

Salt spray testing was carried out in a salt spray chamber of the capacity $0.17 \mathrm{~m}^{3}$ (ASCOTT, Staffs, Great Britain). Testing was carried out according to the International Standard Organization (ISO) standard 9227-2006 »Corrosion tests in the artificial atmosphere«. The concentration of sodium chloride solution was $50 \mathrm{~g} / \mathrm{L}(5 \pm 1 \%)$.

The device for spraying the salt solution comprised a supply of clean air, of controlled pressure and humidity. The temperature of the hot water in the saturation tower was $46{ }^{\circ} \mathrm{C}$ and the overpressure was $85 \mathrm{kPa}$. The temperature in the salt spray chamber was set to $35^{\circ} \mathrm{C} \pm 2{ }^{\circ} \mathrm{C}$. The test lasted 6 hours. 


\section{CORROSION RESISTANCE OF CERIUM-CONVERSION COATINGS FORMED FROM CERIUM(III) SALTS ON ALUMINIUM ALLOY 7075-T6}

The samples were taken from the chamber every few hours and photographed in order to follow the progress of the corrosion process with time. Micrographs were taken by a digital camera.

\section{SEM characterization}

A scanning electron microscope (SEM) JSM-7600F (JEOL) and an energy dispersive X-ray spectrometer (EDS) Inca 350 (Oxford Instruments) were used to analyse the morphology and chemical composition of bare and coated AA7075-T6 substrates. Prior analysis, the samples were coated with a thin layer of carbon. SEM analysis was performed in a backscattered electron (BSE) mode with beam energy of 5 or $15 \mathrm{kV}$. EDS analysis were performed in point mode and the carbon was omitted from quantitative analysis.

\section{ACKNOWLEDGMENTS}

The financial support by Slovenian Research Agency is kindly acknowledged (core projects No. P2-0393 and No. P1-0134). This work is a part of the micro-grant Key enabling technology for clean production (abbreviation KET4CP) "Surface treatment process implementation for aluminium sealing to improve anti-corrosion properties", agreement No. KET4CP-SME2019-06No-01". The authors thank Barbara Kapun for performing SEM/EDS analysis.

\section{REFERENCES}

1. J.E. Hatch, Aluminum: Properties and Physical Metallurgy, ASM International, 1984.

2. J.R. Davis, Corrosion of Aluminum and Aluminum Alloys, ASM International, 1999.

3. P.L. Hagans; C.M. Haas; Surf. Eng. 1994, 5, 405-411.

4. M. Kendig; S. Jeanjaquet; R. Addison; J. Waldrop; Surf. Coat. Technol., 2001, 140, 58-66.

5. ECHA European Chemicals Agency, Chromium VI compounds - ANNEX XVII TO REACH - Conditions of restrictions, https://echa.europa.eu.

6. I. Milošev; Acta Chim. Slov., 2019, 66, 511-533.

7. O. Gharbi; S. Thomas; C. Smith; N. Birbilis; Npj Mater. Degrad., 2018, 12, 1-8.

8. B.R.W. Hinton, D.R. Arnott, N.E. Ryan; Met. Forum, 1984, 7, 211-217.

9. B. Hinton; Corrosion, 2010, 66, 085001-085001-15.

10. F.H. Scholes; C. Soste; A.E. Hughes; S.G. Hardin; P.R. Curtis; Appl. Surf. Sci., 2006, 253, 1770-1780. 
11. M. Forsyth; B. Hinton; Rare Earth-Based Corrosion Inhibitors, Elsevier, 2014.

12. C.-S. Lin; W.-J. Li; Mater. Trans., 2006, 47, 1020-1025.

13. A. Decroly; J.-P. Petitjean; Surf. Coat. Technol., 2005, 194, 1-9.

14. M. Dabalà; L. Armelao; A. Buchberger; I. Calliari; Appl. Surf. Sci. 2001, 172, 312-322.

15. T.G. Harvey; Corros. Eng. Sci. Technol., 2013, 48, 248-269.

16. P. Rodič; I. Milošev; J. Electrochem. Soc. 2016, 163, C85-C93.

17. I. Milošev; P. Rodič; Corrosion, 2016, 72, 1021-1034.

18. B. Volarič; I. Milošev; Corros. Eng. Sci. Technol., 2017, 52, 201-211.

19. P. Rodič; I. Milošev; Corros. Sci. 2019, 149, 108-122.

20. P. Rodič; I. Milošev; M. Lekka; F. Andreatta; L. Fedrizzi; Electrochim. Acta. 2019, 308, 337-349.

21. I. Milošev; B. Volarič; Corrosion, 2017, 73, 822-843.

22. B. Volarič; A. Mazare; S. Virtanen; I. Milošev; Corrosion, 2020, 76, 18-38.

23. F. Andreatta; M.M. Lohrengel; H. Terryn; J.H.W. de Wit; Electrochim. Acta, 2003, 68, 3239-3247. 